\title{
Pengaruh Current Ratio, DER dan Struktur Aktiva terhadap ROA pada Perusahaan Sub Sektor Semen yang Terdaftar di BEI
}

\author{
*Ardelia Novita Putri \\ Program Studi Manajemen Fakultas Ekonomi dan Bisnis \\ Universitas Bhayangkara Surabaya, Indonesia
}

DOI: $10.46821 /$ benchmark.v2i1.219

\begin{abstract}
Abstrak
Penelitian ini bertujuan untuk mengetahui pengaruh dari variabel bebas yaitu Current Ratio, DER dan Struktur Aktiva terhadap variabel terikatnya yaitu ROA. Penelitian ini dilakukan pada perusahaan semen yang terdaftar di BEI periode 2016-2019. Analisis data yang digunakan yaitu analisis regresi linier berganda dengan aplikasi SPSS 23. Teknik sampel penelitian menggunakan purposive sampling dan diperoleh sample sebesar 6 perusahaan dari perusahaan semen yang terdaftar di BEI periode 2016-2019. Secara simultan hasil yang didapatkan dari penelitian ini adalah variabel Current Ratio, DERdan Struktur Aktiva berpengaruh signifikan terhadap ROA. Secara parsial hasil menunjukkan bahwa hanya Struktur Aktiva yang memiliki pengaruh signifikan terhadap ROA, sedangkan Current Ratio dan DER berpengaruh tidak signifikan terhadap ROA.

Kata Kunci: Current Ratio, Debt to Equity Ratio, Struktur Aktiva, Return on Asset.

Abstract

This research is aimed to understand the effect of the independent variables such as Current Ratio, DER and Asset Structure on the dependent variable, ROA. This research was conducted at cement companies listed on the IDX in period 2016-2019. Data analysis used is multiple linear regression analysis with the SPSS 23 application. The sample technique used purposive sampling and obtained a sample of 6 companies from cement companies listed on the IDX for the period 2016-2019. Simultaneously, the results obtained from this research are the variables Current Ratio, DER and Asset Structure have a significant effect on ROA. Partially the results show that only the Asset Structure has a significant effect on ROA, while the Current Ratio and DER have no significant effect on ROA.
\end{abstract}

Keywords: Current Ratio, Debt to Equity Ratio, Asset Structure, Return on Asset.

\section{PENDAHULUAN}

Setiap perusahaan memiliki laporan keuangan yang dijadikan sebagai sumber informasi terutama bagi pihak internal maupun pihak eksternal perusahaan. Untuk melihat baik buruknya kondisi perusahaan, maka perlu dilihat di laporan keuangannya karena laporan keuangannya tersebut menggambarkan kinerja perusahaan. Laporan keuangan biasanya berisi hal-hal daftar neraca, perhitungan laba rugi, laporan dan sumber penggunaan dana, serta laporan arus kas (Jumingan, 2018:4).

Dalam Sub Sektor Semen terdapat 6 perusahaan yang tercatat di Bursa Efek Indonesia dan semuanya telah menggunakan IPO (Initial Public Offering), yaitu mengacu pada proses penjualan saham atau obligasi oleh perusahaan yang hendak go publik kepada masyarakat.

*Corresponding Author:

Hal: $25-33$

Email: ardelianovitaputri@gmail.com 
Alasan peneliti memilih subsektor ini dikarenakan semen adalah jenis material yang selalu digunakan dalam pengerjaan proyek pembuatan gedung dan bangunan. Peneliti melakukan penelitian ini untuk mengetahui seberapa besar laba yang dapat dihasilkan oleh perusahaan sub sektor semen ini dengan kekayaan yang dimilikinya. Serta peneliti ingin membantu para investor yang ingin menanamkan sahamnya pada perusahaan ini dengan tujuan investor dapat mengambil keputusan yang tepat untuk menanamkan sahamnya atau tidak.

Untuk menilai seberapa efektif perusahaan dalam menghasilkan laba, dapat dilakukan dengan menggunakan perhitungan rasio keuangan. Rasio keuangan merupakan kegiatan membandingkan angka-angka yang ada dalam laporan keuangan dengan cara membagi satu angka dengan angka lainnya (Kasmir, 2017:104). Dengan mencari rasio keuangan maka perusahaan dapat mengevaluasi kinerja yang dicapai manajemen perusahaan di masa yang lalu dan juga untuk bahan pertimbangan dalam menyusun rencana perusahaan kedepan (Sudana, 2015:23).

Rasio yang digunakan dalam penelitian ini adalah Return on Asset,Current Ratio, Debt to Equity Ratio dan struktur Aktiva. Faktor-faktor dari Return On Asset yang digunakan untuk penelitian ini adalah pada kondisi intern perusahaan yang berkaitan dengan Current Ratio, Debtto Equity Ratio dan Struktur Aktiva. Untuk itu. Penulis ingin mengetahui apakah ada pengaruh yang terjadi terhadap kemampuan perusahaan dalam menghasilkan laba dengan melihat kemampuan perusahaan dalam memenuhi kewajibannya. Jika ketiga alat ukur tersebut berpengaruh, maka manajer atau pimpinan perusahaan bisa mengambil keputusan berdasarkan rasio-rasio tersebut dan juga sebagai alat pertimbangan bagi investor untuk menanamkan sahamnya atau tidak.

\section{TINJAUAN PUSTAKA}

\section{Current Ratio}

Menurut Kasmir (2017:134), current ratio merupakan rasio untuk mengukur kemampuan perusahaan dalam membayar kewajiban jangka pendek atau utang yang segera jatuh tempo pada saat ditagih secara keseluruhan. Dengan kata lain, seberapa banyak aktiva lancar yang tersedia untuk menutupi kewajiban jangka pendek yang segera jatuh tempo. Dapat dirumuskan sebagai berikut:

Current Ratio $=\frac{\text { Aktiva Lancar }}{\text { Utang Lancar }}$

\section{Debt to Equity Ratio (DER)}

Menurut Kasmir (2017:157), Debt to Equity Ratio merupakan rasio yang digunakan untuk menilai utang dengan ekuitas. Rasio ini berfungsi untuk mengetahui setiap rupiah modal sendiri yang dijadikan untuk jaminan utang. Bagi kreditur, DER yang tinggi menunjukkan kinerja keuangan kurang baik, karena semakin banyak utang perusahaan dan semakin banyak pula beban bunga utang yang ditanggung oleh perusahaan.Rumus DER adalah sebagai berikut:

DER $=\frac{\text { Total Utang }}{\text { Ekuitas }}$ 
Struktur Aktiva

Menurut Syamsuddin (2018;9) adalah penentuan berapa besarnya alokasi untuk masingmasing komponen aktiva, baik aktiva lancar maupun aktiva tetap.Penentuan struktur aktiva yang baik bagi perusahaan bukanlah tugas yang mudah. Struktur aktiva dapat dipandang dari objek operasional yang pada dasarnya menggolongkan aktiva dalam perbandingan tertentu untuk keperluan operasi utama perusahaan. Struktur aktiva dipandang dari aktiva yang harus disediakan untuk operasional perusahaan secara permanen, yaitu aktiva tetap. Karena pada perusahaan industri, aktiva perusahaan lebih banyak dialokasikan dalam bentuk aktiva tetap. Formulasi dari struktur aktiva adalah sebagai berikut:

Struktur Aktiva $=\frac{\text { Aktiva Tetap }}{\text { Total Aktiva }}$

\section{Return On Asset (ROA)}

Menurut Kasmir (2017:201) Return on Asset merupakan rasio yang menunjukkan hasil (return) atas jumlah aktiva yang digunakan dalam perusahaan. Formula menghitung nya adalah sebagai berikut:

ROA $=\frac{\text { Laba Bersih Setelah Pajak }}{\text { Total Aktiva }}$

\section{METODE PENELITIAN}

\section{Teknik Penentuan Populasi \& Sampel}

Populasi yang diamati dalam penelitian ini adalah perusahaan sub sektor semen yang terdaftar di BEI berjumlah 6 perusahaan. Untuk teknik pengambilan sample dalam penelitian ini dilakukan secara purposive sampling. Oleh karena itu jumlah sample yang memenuhi kriteria sebanyak 6 perusahaan dengan pengamatan kinerjanya selama 4 tahun.

\section{Lokasi dan Waktu Penelitian}

Penelitian ini dilakukan dengan mengambil laporan keuangan tahunan pada perusahaanperusahaan subsektor semen yang terdaftar di BEI secara online melalui website www.idx.co.id yang merupakan website resmi dari Bursa Efek Indonesia.

\section{Metode Pengumpulan Data}

Teknik pengumpulan data yang digunakan dalam penelitian ini adalah menggunakan studi dokumentasi dengan mengumpulkan data sekunder dimana data tersebut telah disediakan oleh BEI berupa Laporan Keuangan perusahaan periode 2016-2019 dengan pendekatan kuantitatif

\section{Teknik Analisis Data \& Uji Hipotesis}

Dalam menentukan model regresi yang valid, maka penelitianini menggunakan uji asumsi klasik yang bertujuan untuk menguji apakah data tersebut terbebas dari masalah asumsi klasik. Uji asumsi klasik terdiri dari 4 uji yaitu uji normalitas, uji multikolinieritas, uji hetereroskedatisitas dan uji autokorelasi.

Teknik analisis data yang digunakan dalam penelitian ini adalah analisis regresi linear berganda. Dengan rumus sebagai berikut:

$\mathrm{Y}=\mathrm{a}+\mathrm{b} 1 \mathrm{X} 1+\mathrm{b} 2 \mathrm{X} 2+\mathrm{b} 3 \mathrm{X} 3+\mathrm{ei}$ 
Uji hipotesis yang digunakan dalam penelitian ini adalah dengan menggunakan Uji $\mathrm{F}$ (Simultan), Uji t (Parsial) dan penentuan Variabel Dominan. Pengambilan keputusan didasarkan dari hasil pengelolahan data melalui program SPSS 23 menggunakan tingkat sigfikansi sebesar $0,05(\alpha=5 \%)$.

Setelah dihitung menggunakan SPSS maka langkah selanjutnya yaitu membandingkan hasil nilai signifikan tabel dengan nilai tingkat signifikansi dan nilai hitung dengan nilai tabel.

\section{HASIL ANALISIS DAN PEMBAHASAN}

Dalam menentukan model regresi yang valid, maka data yang harus diuji terdapat 4 uji apakah terbebas dari masalah asumsi klasik. Pertama, Uji Normalitas bertujuan untuk menguji apakah residualnya mempunyai distribusi normal atau tidak.Uji normalitas yg digunakan yaitu Uji Kolmogorov-Smirnov. Berdasarkan pengamatan hasil tabel yang didapat bahwa diketahui hasil nilai sig. Sebesar 0,200 yang berarti $>0,05$. Sehingga dapat disimpulkan bahwa nilai residual atau data tersebut berdistribusi normal dan layak untuk dipakai dalam analisis selanjutnya.

Kedua, Uji Multikolinieritas digunakan untuk mengetahui apakah ada atau tidaknya korelasi yang sangat kuat diantara variabel independen dalam model regresi. Berdasarkan pengamatan hasil tabel yang didapat diketahui bahwa hasil nilai tolerance untuk data CR, DER dan SA > 0,10 sedangkan untuk nilai VIF CR, DER dan SA < 10,00. Sehingga dapat disimpulkan bahwa data dari masing-masing variabel tersebut tidak terjadi multikolinieritas dan layak untuk dipakai dalam analisis selanjutnya.

Ketiga, Uji heteroskedatisitas digunakan untuk mengetahui apakah ada atau tidaknya penyimpangan ketidaksamaan varians dari residual untuk semua pengamatan pada model regresi. Berdasarkan pengamatan hasil tabel yang didapat diketahui bahwa nilai sig. (2-tailed) CR, DER dan Struktur Aktiva $>0,05$. Sehingga dapat disimpulkan bahwa data tersebut tidak terjadi heteroskedatisitas dan layak untuk dipakai dalam analisis selanjutnya.

Keempat, Uji Autokorelasi digunakan untuk mengetahui apakah dalam suatu model regresi linear terdapat korelasi antara kesalahan pengganggu pada periode tertentu dengan kesalahan pengganggu pada periode selanjutnya.Uji Autokorelasi yang digunakan adalah durbin-watson, Pengujian ini dilakukan dengan membandingkan antara nilai hitung Durbin-Watson dengan nilai tabel Durbin-Watson. Berdasarkan hasil tabel yang didapat diketahui bahwa nilai Durbin-Watson (d) dari model regresi sebesar 1,609. Dari tabel Durbin-Watson dengan signifikansi 0,5 jumlah sampel (n) sebanyak 24 dan jumlah variabel bebas $(\mathrm{k})$ sebanyak 3 diperoleh nilai dl sebesar 1,1010 dan nilai du sebesar 1,6565. Karena nilai $\mathrm{d}=1,609$ berada pada daerah diantara $\mathrm{dl}=1,1010 \mathrm{dan} \mathrm{du}=1,6565$ atau $\mathrm{dl}<\mathrm{d}<\mathrm{du}$ yang artinya tidak menghasilkan kesimpulan yang pasti.

Sehingga dapat menggunakan uji autokorelasi run testyang berguna untuk mengetahui ada atau tidaknya gejala autokorelasi pada persamaan regresi dalam penelitian ini apabila data Durbin-Watson tidak menampilkan kesimpulan yang pasti. Berikut ini adalah hasil uji autokorelasi run test, Berdasarkan hasil tabel yang didapat diketahui bahwa nilai Asymp. Sig. (2-tailed) sebesar 0,144 $>0,05$ maka dapat disimpulkan data tidak terjadi gejala autokorelasi.

Pengujian koefisien regresi berganda dilakukan untuk mengetahui hubungan dua variabel atau lebih. Pengujian ini digunakan sebagai dasar dalam pengambilan keputusan 
diterima atau tidaknya hipotesis yang diajukan dalam penelitian. Berikut ini adalah hasil analisis regresi linier berganda, Adapun persamaan regresi yang didapat adalah sebagai berikut:

$\mathrm{Y}=0,107+0,008 \mathrm{X}_{1}-0,022 \mathrm{X}_{2}-0,094 \mathrm{X}_{3}$

Interpretasi yang didapatkan dari persamaan regresi diatas adalah sebagai berikut : 1) konstanta (a) sebesar 0,107 yang artinya jika nilai current ratio, debt to equity ratio dan struktur aktiva $=0$ (nol) maka nilai return on asset yaitu sebesar 0,107 satuan. 2) Nilai koefisien $\left(\beta_{1}\right)$ sebesar 0,008 yang artinya setiap current ratio meningkat satu satuan, maka akan diikuti oleh peningkatan return on asset sebesar 0,008 dengan asumsi variabel independen yang lain dianggap konstan. 3) Nilai koefisien $\left(\beta_{2}\right)$ sebesar -0,022 yang artinya setiap debt to equity ratio meningkat satu satuan, maka akan terjadi penurunan pada nilai return on asset sebesar 0,022 dengan asumsi variabel yang lain dianggap konstan. 4) Nilai koefisien $\left(\beta_{3}\right)$ sebesar -0,094 yang artinya setiap struktur aktiva meningkat satu satuan, maka akan terjadi penurunan pada nilai return on asset sebesar 0,094 dengan asumsi variabel yang lain dianggap konstan.

\section{Pengaruh Current Ratio, Debt to Equity Ratio dan Struktur Aktiva Secara Simultan terhadap variabel Return On Asset}

Uji Simultan (Uji F) dilakukan untuk menguji pengaruh variabel independensecara keseluruhan atau bersama-sama terhadap variabel dependen return on asset. Berikut ini merupakan hasil pengujian secara simultan yang diperoleh dari SPSS 23 dapat dilihat pada Tabel 1.

Berdasarkan Tabel 1 dapat diketahui bahwa nilai $\mathrm{F}_{\text {hitung }}$ diperoleh sebesar 10,229 dengan tingkat signifikan 0,000. Pada $(\alpha)=0,05$ dengan $\mathrm{k}=3$ dan $\mathrm{n}=24$, maka diketahui bahwa $F_{\text {tabel }}$ sebesar 3,07. Jadi, nilai $F_{\text {hitung }}>F_{\text {tabel }}$ yaitu sebesar 10,299 > 3,07 maka dapat disimpulkan bahwa hipotesis diterima. Pengambilan keputusan dapat dilihat juga dari tingkat signifikansi, diketahui bahwa tingkat signifikasi pada tabel diatas yaitu sebesar 0,000. Karena nilai signifikasi lebih kecil dari 0,05, sehingga dapat disimpulkan bahwa variabel Current Ratio, Debt to Equity Ratio dan Struktur Aktiva secara simultan berpengaruh signifikan terhadap Return on Asset pada Perusahaan Sub Sektor Semen yang terdaftar di Bursa Efek Indonesia periode 2016-2019.

Tabel 1

Hasil Uji Hipotesis Simultan (Uji F)

ANOVA $^{\mathrm{a}}$

\begin{tabular}{|c|c|c|c|c|c|}
\hline Model & Sum of Squares & $\mathrm{Df}$ & Mean Square & $\mathrm{F}$ & Sig. \\
\hline 1 Regression & , 020 & 3 & , 007 & 10,229 &, $000^{\mathrm{b}}$ \\
\hline Residual & ,013 & 20 & , 001 & & \\
\hline Total & ,034 & 23 & & & \\
\hline
\end{tabular}

a. Dependent Variable: ROA

b. Predictors: (Constant), SA, DER, CR

Sumber: Data Sekunder Diolah (2021) 
Maka dari itu, Perusahaan perlu untuk menjaga kestabilan antara current ratio, debt to equity ratio dan struktur aktiva dalam meningkatkan return on asset. Hal ini dilakukan agar profitabilitas perusahaan dapat meningkat setiap tahunnya. Perusahaan juga perlu mengurangi peminjaman dana dari kreditur serta perlu mengelola penggunaan aktiva dengan baik agar tidak ada nilai yang terbuang dengan sia-sia.

Uji t digunakan untuk menguji pengaruh variabel independen secara parsial terhadap variabel dependen, yaitu pengaruh dari masing-masing variabel independen yang terdiri dari current ratio, debt to equity ratio dan struktur aktiva terhadap return on asset. Data hasil pengujian secara parsial yang diperoleh dari SPSS 23 dapat dilihat pada Tabel 2. Berdasarkan tabel 2 dapat diketahui pengaruh dari masing-masing variabel terhadap variabel terikatnya, maka dapat di interpretasikan dengan ketentuan berikut.

\section{Pengaruh Current Ratio Terhadap Retun on Asset}

Berdasarkan tabel uji t diatas, uji $\mathrm{t}$ antara current ratio dengan return on asset menunjukkan hasil $t_{\text {hitung }}$ 0,924 lebih kecil dari $t_{\text {tabel }}$ 2,086 dengan nilai signifikan sebesar 0,367>0,05 maka dapat disimpulkan bahwa current ratio secara parsial memiliki pengaruh tidak signifikan terhadap return on asset.

Hal ini menunjukkan bahwa tinggi rendahnya current ratio akan mempengaruhi return on asset tetapi pengaruhnya tidak besar, dikarenakan peningkatan aktiva lancar kurang besar dibandingkan dengan utang lancar.

Untuk meningkatkan nilai aktiva lancar, perusahaan perlu mengelola persediaan dengan baik, menagih piutang dengan segera, serta memanfaatkan pembiayaan gratis dari pemasok dengan baik dan efisien.

\section{Pengaruh Debt to Equity Ratio Terhadap Retun on Asset}

Berdasarkan tabel uji $\mathrm{t}$ diatas, uji $\mathrm{t}$ antara debt to equity ratio dengan return on asset menunjukkan hasil $t_{\text {hitung }}-1,455$ lebih kecil dari $t_{\text {tabel }}$ 2,086 dengan nilai signifikan sebesar 0,161>0,05 maka dapat disimpulkan bahwa debt to equity ratio secara parsial memiliki pengaruh tidak signifikan terhadap return on asset.

Tabel 2

Uji Parsial (Uji t) Coefficients $^{\mathrm{a}}$

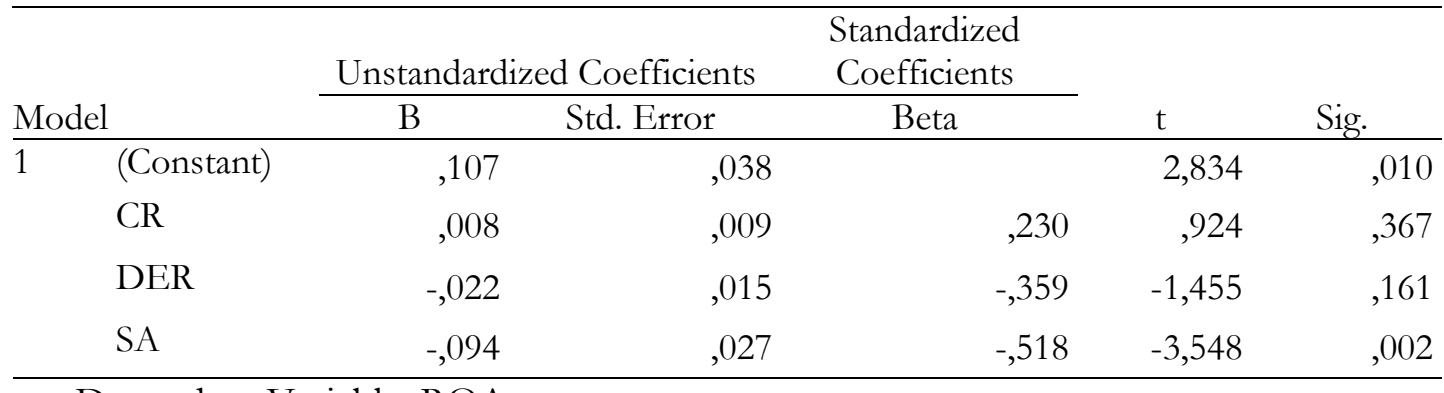

a. Dependent Variable: ROA

Sumber : Data Sekunder Diolah (2021) 
Hal ini menunjukkan bahwa tinggi rendahnya nilai debt to equity ratio akan mempengaruhi profitabilitas tetapi pengaruhnya tidak besar, dikarenakan peningkatan total utang lebih meningkat pesat dibandingkan dengan ekuitas. Semakin tinggi debt to equity ratio akan mempengaruhi besarnya laba (return on asset) yang dicapai oleh perusahaan. Semakin besar rasio ini berarti semakin kecil modal sendiri di dalam menjamin hutangnya, sehingga bagi perusahaan akan semakin beresiko.

\section{Pengaruh Struktur Aktiva Terhadap Retun on Asset}

Berdasarkan tabel uji $\mathrm{t}$ diatas, uji $\mathrm{t}$ antara struktur aktiva dengan return on asset menunjukkan hasil $t_{\text {hitung }}-3,548$ lebih besar dari $t_{\text {tabel }}$ 2,086 dengan nilai signifikan sebesar 0,002<0,05 maka dapat disimpulkan bahwa struktur aktiva secara parsial memiliki pengaruh yang signifikan terhadap return on asset.

Hal ini menunjukkan bahwa tinggi rendahnya nilai struktur aktiva akan mempengaruhi profitablilitas perusahaan. Perusahaan yang memiliki aset tetap dalam jumlah besar dapat menggunakan dana dalam jumlah besar oleh karena itu penyediaan aktiva tetap dan total aktiva yang besar terkadang akan digunakan perusahaan untuk keperluan yang tidak berarti dikarenakan skalanya perusahaan besar akan lebih mudah mendapatkan akses ke sumber dana dibandingkan ke jaminan utang perusahaan, sehingga kemampuan perusahaan dalam meningkatkan laba menjadi berkurang. Perusahaan harus memanfaatkan aktiva dengan baik dan efektif agar tidak ada penggunaan yang tidak berarti yang dapat mengurangi nilai aktivanya.

\section{Penentuan Variabel Dominan}

Untuk mengetahui variabel mana yang dominan pengaruhnya diantara variabel bebas (X) terhadap variabel terikat yaitu return on asset (Y) dilihat dari koefisien beta yang tertinggi dari setiap variabel, dengan melihat rangking koefisien regresi yang distandartkan $(\beta)$ atau Standarzied of Coefficients Beta dari masing-masing variabel bebas, yang menjadi variabel dominan adalah struktur aktiva, karena memiliki nilai beta tertinggi diantara variabel independen lainnya yaitu sebesar $-0,518$ dengan nilai signifikan 0,002 .

\section{Koefisien Determinasi $\left(\boldsymbol{R}^{\mathbf{2}}\right)$}

Berdasarkan hasil penelitian, diketahui nilai R-Square $\left(\mathrm{R}^{2}\right)$ atau koefisien determinasi adalah sebesar 0,605. Angka ini mengidentifikasikan bahwa Return on Asset (variabel dependen) mampu dijelaskan oleh Current Ratio, Debt to Equity Ratio dan Struktur Aktiva (variabel independen) sebesar 60,5\% sedangkan sisanya sebesar 39,5\% dapat dijelaskan oleh faktor-faktor lain yang tidak ada dalam penelitian ini.

\section{SIMPULAN DAN SARAN}

Berdasarkan hasil penelitian yangdilakukan, maka dapat diambil kesimpulan yaitu sebagai berikut: (1) Bahwa variabel Current Ratio, Debt to Equity Ratio dan Struktur Aktiva secara simultan berpengaruh signifikan terhadap Return on Asset pada Perusahaan Sub Sektor Semen yang terdaftar di Bursa Efek Indonesia. (2) Bahwa Current Ratio berpengaruh tidak signifikan terhadap variabel Return on Asset. Debt to Equity Ratio secara parsial berpengaruh tidak signifikan terhadap Return on Asset. Struktur Aktiva secara parsial berpengaruh signifikan terhadap Return on Asset pada Perusahaan Sub Sektor Semen yang terdaftar di Bursa Efek Indonesia. (3) Variabel Struktur Aktiva merupakan variabel yang dominan karena mempunyai koefisien beta tertinggi dibanding variabel bebas lainnya. 
Adapun saran bagi perusahaan diharapkan untuk menjaga kestabilan likuiditasnya agar tidak terlalu rendah dan juga tidak terlalu tinggi. Perusahaan juga perlu memperhatikan kondisi me ningkatnya DER serta menjaga kestabilan dalam mengelola modal sendiri agar tidak terlalu menambah dana yang besar dari kreditur sehingga dapat meningkatkan profitabilitas. Saran bagi kreditur sebaiknya mempertimbangkan untuk bekerja sama dengan perusahaan mengingat tingkat current ratio perusahaan mengalami penurunan secara rata-rata yang artinya perusahaan kurang mampu membayar kewajiban jangka pendeknya sebelum jatuh tempo. Saran bagi investor sebaiknya mempertimbangkan untuk menanamkan saham atau berinvestasi pada perusahaan ini, karena nilai debt to equity ratio perusahaan mengalami peningkatan secara rata-rata sehingga resiko yang ditanggung cukup besar. Saran bagi peneliti selanjutnya diharapkan menggunakan variabel.

\section{DAFTAR PUSTAKA}

Fahmi, I. (2018). Analisis Laporan Keuangan. Bandung: Alfabeta.

Hani, S. (2015). Teknik Analisa Laporan Keuangan. Medan: In Media.

Hantono. (2015). Pengaruh Current Ratio, Debt to Equity Ratio Terhadap Profitabilitas Pada Perusahaan Manufaktur Sektor Logam dan Sejenisnya yang Terdaftar Di Bursa Efek Indonesia Periode 2009-2013. JWEM STIE MIKROSIL, Vol.5 No.1.

Harahap, S. S. (2016). Analisis Kritis Atas Laporan Keuangan. Jakarta: Raja Grafindo Persada.

Harjito, A., \& Martono. (2017). Manajemen Keuangan, Edisi Kedua. Yogyakarta: Ekonisia.

Hery. (2015). Analisis Laporan Keuangan, Pendekatan Rasio Keuangan . Yogyakarta: CAPS Publishing.

Jumingan. (2018). Analisis Laporan Keuangan . Jakarta: Bumi Aksara.

Kasmir. (2017). Analisis Laporan Keuangan. Jakarta: Raja Grafindo Persada.

Munawir. (2016). Analisa Laporan Keuangan, Edisi Keempat. Yogyakarta: Liberty.

Prihadi, T. (2018). Analisis Laporan Keuangan, Teori dan Aplikasi. Jakarta: PPM Manajemen.

Priyatno, D. (2013). Mandiri Belajar Analisa Data Dengan SPSS. Yogyakarta: Mediakom.

Riyanto, B. (2015). Dasar-Dasar Pembelanjaan Perusahaan, Edisi Keempat. Yogyakarta: GPFE.

Sartono, A. (2015). Manajemen Keuangan Teori dan Aplikasi. Yogyakarta: BPFE. 
Sudana, I. M. (2015). Manajemen Keuangan Perusahaan, Edisi Kedua . Jakarta: Erlangga.

Sugiyono. (2015). Metode Penelitian Kuantitatif, Kualitatif dan R\&D. Bandung: Alfabeta.

Sujarweni, V. W. (2017). Analisis Laporan Keuangan, Teori, Aplikasi dan Hasil Penelitian . Yogyakarta: Pustaka Baru Press.

Syamsuddin, L. (2018). Manajemen Keuangan Perusahaan, Konsep Aplikasi Dalam Perencanaan, Pengawasan dan Pengambilan Keputusan, Edisi Baru. Jakarta: Raja Grafindo Persada.

Widoatmojo, S. (2015). Pengetahuan Pasar Modal . Jakarta : Gramedia.

Yudiana, F. E. (2013). Dasar-Dasar Manajemen Keuangan, Memahami Dasar-Dasar Manajemen Keuangan Secara Mudah dan Sederhana . Yogyakarta: Ombak.

Zulfikar. (2016). Pengantar Pasar Modal dengan Pendekatan Statistika. Yogyakarta: Deepublish. 